\title{
Stereotype Threat and Racial Differences in Citizens' Experiences of Police Encounters
}

\author{
Cynthia J. Najdowski \\ University at Albany, State University of New York
}

\author{
Bette L. Bottoms \\ University of Illinois at Chicago
}

\author{
Phillip Atiba Goff \\ University of California, Los Angeles
}

\begin{abstract}
We conducted 2 studies to investigate how cultural stereotypes that depict Blacks as criminals affect the way Blacks experience encounters with police officers, expecting that such encounters induce Blacks to feel stereotype threat (i.e., concern about being judged and treated unfairly by police because of the stereotype). In Study 1, we asked Black and White participants to report how they feel when interacting with police officers in general. As predicted, Blacks, but not Whites, reported concern that police officers stereotype them as criminals simply because of their race. In addition, this effect was found for Black men but not Black women. In Study 2, we asked Black and White men to imagine a specific police encounter and assessed potential downstream consequences of stereotype threat. Consistent with Study 1, Black but not White men anticipated feeling stereotype threat in the hypothetical police encounter. Further, racial differences in anticipated threat translated into racial differences in anticipated anxiety, self-regulatory efforts, and behavior that is commonly perceived as suspicious by police officers. By demonstrating that Blacks might expect to be judged and treated unfairly by police because of the negative stereotype of Black criminality, this research extends stereotype threat theory to the new domain of criminal justice encounters. It also has practical implications for understanding how the stereotype could ironically contribute to bias-based policing and racial disparities in the justice system.
\end{abstract}

Keywords: stereotype threat, race, nonverbal behavior, police, racial profiling

There is an abundance of scientific research demonstrating harmful consequences of negative beliefs about Blacks. Particularly relevant for understanding the origins of racial disparities in criminal justice outcomes is the widely documented stereotype that depicts Blacks as violent and prone to crime (see, e.g., Oliver, 2003; Rome, 2004; Welch, 2007). Duru (2004) traced the roots of this stereotype to the 16th century, when European explorers first encountered and enslaved Black men. However, contemporary studies show that this stereotype continues to be a part of our culture. For instance, aggressiveness and a tendency toward violence are identified as stereotypical attributes of Blacks by both Whites and Blacks (Krueger, 1996; Madon et al., 2001) and

This article was published Online First June 1, 2015.

Cynthia J. Najdowski, School of Criminal Justice, University at Albany; Bette L. Bottoms, Department of Psychology, University of Illinois at Chicago; Phillip Atiba Goff, Department of Psychology, University of California, Los Angeles.

Parts of this work are based on the first author's dissertation, which was completed at the University of Illinois at Chicago. We thank Christian Meissner, Mary Murphy, and Sarah Ullman for their thoughtful comments on this work. We also thank Anastasia Bora, Gretchen Kemner, Jessica Spanton, Jessica Walker, Catherine Bonventre, Laura Fleig, Ellen Kim, Jordan Dolgos, and Meagen Hildebrand for their research assistance.

Correspondence concerning this article should be addressed to Cynthia J. Najdowski, School of Criminal Justice, University at Albany, 135 Western Avenue, DR-219, Albany, NY 12222. E-mail: cnajdowski@albany.edu criminality and hostility are among the features most commonly endorsed as stereotypic of Blacks by both high-prejudiced and low-prejudiced Whites (Devine, 1989; Devine \& Elliot, 1995).

A substantial body of psychological research has established that the cultural stereotype of Black criminality can have a subtle yet biasing influence on the way that people perceive individuals, process information, and form judgments, even absent any conscious bias on the part of the perceiver (e.g., Devine, 1989; Eberhardt, Goff, Purdie, \& Davies, 2004). By causing the concepts of race and crime to be automatically and inextricably linked, with thoughts of one leading to thoughts of the other, the Black criminal stereotype can unconsciously and automatically influence what police officers see when they encounter Black citizens, how officers interpret what they see, and how they decide to act in response (Devine, 1989; Duncan, 1976; Eberhardt et al., 2004; Graham \& Lowery, 2004; Hurwitz \& Peffley, 1997; Payne, 2001), including determining whether to shoot a suspect (Correll, Park, Judd, \& Wittenbrink, 2002, 2007; Correll, Park, Judd, Wittenbrink, Sadler, et al., 2007; Correll, Urland, \& Ito, 2006).

However, for all the recent attention psychologists have paid to how negative stereotypes can influence perceptions and behaviors toward groups perceived as criminal, there has been relatively little attention paid to how the stereotypes might influence the attitudes and behaviors of the targets themselves. Notable exceptions include Najdowski (2011) and Davis and Leo (2012). Najdowski (2011) suggested that Blacks experience stereotype threat in police encounters, and that this threat can have meaningful deleterious 
effects on encounters with law enforcement figures. Stereotype threat is the concern one experiences when at risk of being perceived in light of a negative stereotype that applies to one's group (Steele, 2010; Steele \& Aronson, 1995; Steele, Spencer, \& Aronson, 2002). Najdowski argued that, in light of the prevalence and power of stereotypes regarding Black criminality, Blacks are concerned they will be judged and treated unfairly by police, in line with those stereotypes. This is concerning because stereotype threat has been shown to have ironic effects on performance and behavior, which inadvertently increase an individual's likelihood of confirming the stereotype (e.g., Bosson, Haymovitz, \& Pinel, 2004; Goff, Steele, \& Davies, 2008; Steele \& Aronson, 1995). As reviewed by Najdowski, stereotype threat might cause Blacks to feel anxious and engage in self-regulatory efforts (e.g., vigilance to threat-related cues, active monitoring efforts) when interacting with the police. As a consequence, Blacks may be more likely than Whites to behave in ways that police commonly perceive as indicative of deception, increasing the likelihood that innocent Blacks will be misclassified as guilty by police. Davis and Leo (2012) further suggested that self-regulatory efforts deplete cognitive capacities in ways that compromise threatened individuals' ability to resist pressure to confess in interrogations. Thus, criminal-justice-related stereotype threat could fundamentally shape Blacks' encounters with the criminal justice system and provoke racial disparities not explained by the intentions of police officers, lawyers, or judges.

Considering this theoretical avenue to racial disparities in adverse criminal justice consequences (e.g., wrongful accusations, arrests, convictions; false confessions; etc.), we sought to begin the critical work of understanding whether Blacks do, in fact, experience stereotype threat in criminal justice encounters. Specifically, in two studies, we investigated whether police encounters create stereotype threat and, thus, different psychological experiences of those encounters for Blacks as compared with Whites. In Study 1, we asked participants to report how they feel when interacting with police officers in general. We also explored whether racial differences in police-related stereotype threat might be moderated by participants' gender. In Study 2, we asked participants to imagine a specific hypothetical police encounter and assessed potential downstream consequences of stereotype threat. Our primary hypothesis was that Blacks, but not Whites, would report experiencing and being affected by stereotype threat in criminal justice encounters. To our knowledge, this research is the first to empirically evaluate how stereotype threat might affect Blacks in situations in which interpersonal interactions can influence justicerelevant outcomes.

\section{Study 1}

The majority of research on Blacks' experiences of stereotype threat has focused on understanding the consequences of negative stereotypes related to intelligence. In their seminal research on this phenomenon, Steele and Aronson (1995) showed that when the stereotype that Blacks are low in intelligence is salient, Black students underperform relative to White students on standardized tests. According to Steele and colleagues (2002), however, "All people have some group or social identity for which negative stereotypes exist. ... And when they are doing things in situations where those stereotypes might apply, they can experience this threat" (p. 390). Najdowski's (2011) hypothesis that police encounters serve as a setting for Blacks to experience stereotype threat is supported by research documenting a negative stereotype that depicts Blacks as prone to crime (Devine, 1989; Devine \& Elliot, 1995). Most Blacks are aware of this stereotype. For example, Sigelman and Tuch (1997) found that $82 \%$ of Blacks think they are perceived as violent by Whites, and Cheryan and Monin (2005) found that $20 \%$ of Blacks reported being misperceived as criminals by strangers. Blacks are more likely than Whites to think that racial profiling is widespread (Carlson, 2004; Ludwig, 2003) and to think they are treated unfairly by police, both in general (Hagan \& Albonetti, 1982; Hagan, Shedd, \& Payne, 2005) and in actual criminal justice encounters (Ludwig, 2003). To our knowledge, however, that criminological and sociological research has not been connected to the literature on stereotype threat. This connection is important to make because it allows us to not only understand racial differences in attitudes toward the police and perceptions of criminal injustice, but to also take the next step and gain insights into how those attitudes and perceptions lead Blacks and Whites to have different psychological experiences of police encounters. In line with Najdowski (2011), we predicted that Blacks, but not Whites, experience stereotype threat in police encounters as concern about being perceived as guilty for crimes not committed. We tested this by surveying Blacks and Whites regarding the extent to which they worry about being perceived unfairly by police officers.

We also sought to test whether gender is associated with the level of stereotype threat individuals report experiencing in police encounters. The stereotype of criminality is associated more commonly not only with Blacks than Whites, but also with men rather than women and, in particular, Black men as compared with Black women (Navarrete, McDonald, Molina, \& Sidanius, 2010; Plant, Goplen, \& Kunstman, 2011; Quillian \& Pager, 2001; Rome, 2004; Sidanius \& Veniegas, 2000; Timberlake \& Estes, 2007). Thus, we expected a gender-related difference in police-related stereotype threat to manifest among Black participants, but not White participants.

\section{Method}

Participants. Participants were 49 Black (37\% men) and 184 White (52\% men) undergraduate psychology students from the University of Illinois at Chicago. Participants were 19 years old on average $(S D=3$ years, range $=17$ to 38 years $)$.

\section{Measures.}

Stereotype threat scale. Five items from a modified version of the Explicit Stereotype Threat Scale (Goff, Steele, \& Davies, 2008; Marx \& Goff, 2005; Marx, Stapel, \& Muller, 2005) assessed stereotype threat specific to police encounters (e.g., "I worry that police officers might stereotype me as a criminal because of my race"). Responses were given on a 7-point scale ranging from -3 (strongly disagree) to 3 (strongly agree) and averaged. This scale has been reliable in past research $(\alpha \mathrm{s}=.76-.85$; Goff, Steele, \& Davies, 2008; Marx \& Goff, 2005; Marx et al., 2005) and it was also reliable in the current study (overall: $\alpha=.77, M$ interitem correlation $=.42$; Blacks: $\alpha=.85, M$ interitem correlation $=.53$; Whites: $\alpha=.69, M$ interitem correlation $=.35$ ).

Demographic factors measures. Participants reported their sex (as a proxy for gender), age, and race/ethnicity. 
Procedure. In exchange for course credit, undergraduate introduction to psychology students completed a self-report survey assessing their experiences of police-related stereotype threat and demographic factors in class, along with various unrelated questionnaires submitted by other researchers during a mass-testing session. All participants were treated according to the guidelines of the University of Illinois at Chicago Institutional Review Board (IRB).

\section{Results}

As hypothesized, a 2 (Race: Black, White) $\times 2$ (Gender: Men, Women) between-subjects analysis of variance revealed a significant main effect of race on the stereotype threat scale, $F(1,229)=$ $78.58, p<.001$, Cohen's $d=.57,95 \%$ confidence interval (CI; $[.43, .70])$. Specifically, Blacks were significantly more likely than Whites to agree that they experience stereotype threat in police encounters (see Figure 1).

Neither the main effect of gender, $F(1,229)=3.37, p=.07$, $d=.00,95 \%$ CI $[-.08, .08]$, nor the Race $\times$ Gender interaction effect reached a significant level, $F(1,229)=2.68, p=.10$, partial $\eta^{2}=.01$. Even so, $t$ tests comparing each subsample's mean score on the stereotype threat scale to the scale midpoint revealed that, whereas both White men, $t(95)=-11.33, p<.001, d=-1.16$, $95 \%$ CI $[-1.41,-.90]$, and White women, $t(87)=-11.77, p<$ $.001, d=-1.25,95 \%$ CI $[-1.53,-.97]$, significantly disagreed that they experienced stereotype threat in police encounters, Black women neither significantly disagreed nor agreed, $t(30)=.24, p=$ $.81, d=.04,95 \%$ CI $[-.31, .39]$, and Black men significantly agreed, $t(17)=2.32, p=.03, d=.55,95 \%$ CI $[.04,1.04]$ (see Figure 1).

\section{Discussion}

Results of Study 1 revealed that Black participants were significantly more likely than White participants to report concerns about being racially stereotyped by police officers. Furthermore, in line with Najdowski's (2011) and our primary hypothesis, Black men, but not Black women, White men, nor White women, agreed that they feel concerned that police officers might judge them unfairly and stereotype them as criminals. This finding is interest-

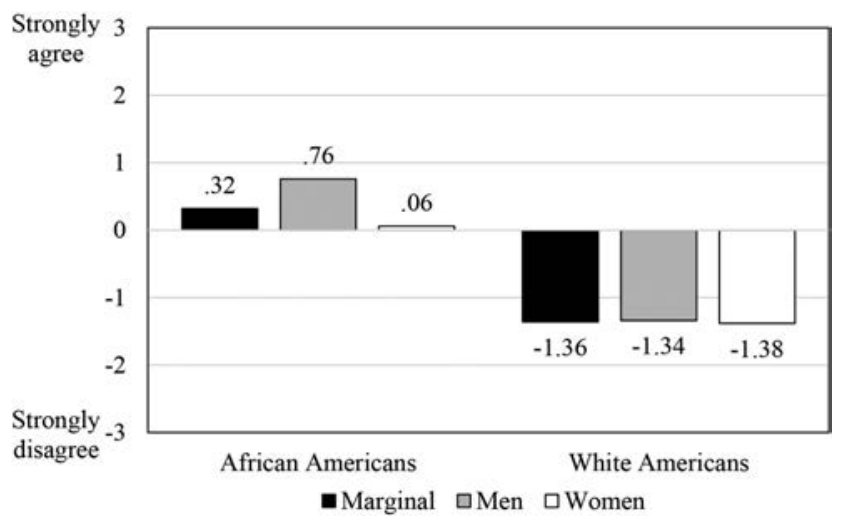

Figure 1. Study 1: Mean ratings of stereotype threat as a function of participant race and gender. ing in light of Goff, Thomas, and Jackson's (2008) intersectional research showing that, compared with White women, Black women are perceived as more masculine and are more often miscategorized as men. On the one hand, for Black women in the context of police encounters, stereotypes associating Black men with criminality may be more salient than those associating "Blackness" with masculinity. On the other hand, recent work by Thomas, Dovidio, and West (2014) suggests that Black women become socially invisible and are less likely than Black men to be categorized according to either race or gender. Although this "intersectional invisibility" (Purdie-Vaughns \& Eibach, 2008) is associated with a host of unfavorable social and political consequences, it might confer the benefit of protecting Black women from the negative stereotype of Black criminality. Future research should explore these ideas.

A limitation of this study is that the questions about police encounters were very abstract. Participants might have had difficulty thinking about how they would feel in police encounters (see, e.g., Ayton, Pott, \& Elwakili, 2007), particularly if they had not had much previous experience interacting with the police. It is possible that they envisioned different kinds of police encounters, and therefore, situations that varied in terms of how likely it would have been for the police officer to target them as suspects. If this method did not facilitate the feeling of a realistic encounter, our findings might underestimate the concerns of participants. Study 2 was conducted to address this limitation and expand our understanding of Blacks' anticipated experiences of police-related stereotype threat.

\section{Study 2}

In Study 2, following Archer, Foushee, Davis, and Aderman (1979) and Haegerich and Bottoms (2000), we asked participants to imagine that they were experiencing a very specific hypothetical police encounter in which it is clear that the officer is in close proximity to and sees the participant, which was not obvious in Study 1. Participants were asked to visualize how they would feel if they were in that situation, allowing us to conduct a better test of our primary hypothesis. We also added new implicit measures of stereotype threat to determine the extent to which thinking about the hypothetical police encounter automatically activated and increased cognitive accessibility of the stereotype of Black criminality. Because stereotypes are activated more in threatened than nonthreatened individuals (Goff, Steele, \& Davies, 2008; Steele \& Aronson, 1995), evidence of stereotype activation might be indicative of stereotype threat. We also assessed stereotype threat more explicitly by asking participants to report their expectations regarding the hypothetical police officer's next actions. We were interested in whether Blacks would be more likely than Whites to expect the officer to initiate investigatory contact with them. The inclusion of these additional measures facilitated a more thorough test of the predicted racial difference in experiences of policerelated stereotype threat.

We also sought to explore some of the downstream effects of stereotype threat on Blacks' experiences in police encounters. As mentioned previously, ironically, stereotype threat can increase an individual's likelihood of performing or behaving in ways that confirm the stereotype (e.g., Steele \& Aronson, 1995). How might this occur in the context of criminal justice settings? Could the 
stereotype of Black criminality increase the likelihood that Blacks will be perceived as criminals? Najdowski (2011) hypothesized that, as a consequence of stereotype threat, Blacks are more likely than Whites to experience anxiety and engage in self-regulatory efforts and, in turn, more likely to engage in nonverbal behaviors that police commonly perceive as deceptive or suspicious.

Indeed, researchers agree that anxiety and self-regulatory efforts are integral components of the psychological process by which threat negatively affects performance and behavior (Major \& O'Brien, 2005; Richeson \& Shelton, 2007, 2012; Schmader, Johns, $\&$ Forbes, 2008). On the one hand, compared with nonthreatened individuals, those under stereotype threat experience more anxietyrelated physiological arousal, including increased blood pressure (Blascovich, Spencer, Quinn, \& Steele, 2001; Lehman \& Conley, 2010) and cardiovascular reactivity (Mendes, Blascovich, Lickel, \& Hunter, 2002; Mendes, Major, McCoy, \& Blascovich, 2008). Further, anxiety translates into behavior. For instance, Harrigan and O'Connell (1996) found that the more uncomfortable, nervous, and apprehensive participants reported feeling while describing the most anxious event they had ever experienced, the more they blinked their eyes, displayed fearful facial expressions, and had movements across their entire faces (see also Gregersen, 2005; Waxer, 1977).

On the other hand, individuals who experience stereotype threat have been shown to self-regulate by becoming vigilant to cues to determine whether they are (a) at risk of being stereotyped and (b) behaving in ways that confirm the stereotype. Such vigilance can disrupt automatic behaviors by bringing them to the forefront of consciousness (Beilock, Jellison, Rydell, McConnell, \& Carr, 2006; Schmader et al., 2008). For example, compared with nonthreatened women, women who are faced with the stereotype that men are better at math are more cognitively vigilant to details about the setting in which threat is induced (Murphy, Steele, \& Gross, 2007) and devote more of their thoughts to worrying about and monitoring their performance on math problems (Beilock, Rydell, \& McConnell, 2007). Furthermore, an extensive literature shows that individuals who think that others have negative beliefs or expectations about them take measures to try to disprove those negative expectations (e.g., Cook, Arrow, \& Malle, 2011; Hilton \& Darley, 1985; Smith, Neuberg, Judice, \& Biesanz, 1997; for review, see Miller \& Myers, 1998). Staples (2007) described one such attempt. As a Black man walking through city streets at night, he recognized that others perceived him as a danger- "a mugger, rapist, or worse" (p. 186). To appear less threatening, Staples began whistling classical music during his walks.

The research reviewed suggests that in the context of police encounters, compared with nonthreatened Whites, threatened Blacks might be more anxious, more vigilant to cues from police officers about whether they will be accused of crime, and more likely to try to reduce this risk by overcontrolling or engaging in counterstereotypical behaviors. However, these psychological effects might manifest in ways that lead police officers to misclassify innocent individuals who are Black as guilty more often than those who are White. In support, individuals under stereotype threat have been shown to display some of the same behaviors that police commonly perceive as suspicious. For example, Vorauer and Turpie's (2004) research on prejudice concerns in interracial interactions revealed that White Canadians who were concerned about how they would be appraised by First Nations Canadian interaction partners engaged in less eye contact than nonthreatened White Canadians (see also Shelton, 2003). Furthermore, Bosson and colleagues (2004) found that, compared with nonthreatened gay men, gay men who were primed to think of the stereotype that depicts gay men as child molesters were perceived by observers as more anxious during interactions with children. Such findings are concerning because, in general, police erroneously believe that lying or guilty individuals are more likely than truthful or innocent individuals to, for example, avoid eye contact and avert their gaze (Akehurst, Köhnken, Vrij, \& Bull, 1996; Mann, Vrij, \& Bull, 2004; Strömwall \& Granhag, 2003; Vrij, Akehurst, \& Knight, 2006; Vrij \& Mann, 2001; Vrij \& Taylor, 2003); appear anxious, tense, or nervous (Akehurst et al., 1996; Vrij et al., 2006; Vrij \& Winkel, 1992); smile (Vrij \& Semin, 1996), or try to control their behavior and speech (Mann \& Vrij, 2006; Vrij et al., 2006). The correspondence of nonverbal behaviors caused by stereotype threat, anxiety, and self-regulatory efforts and those that the police associate with deception might put innocent Blacks at greater risk than Whites of being perceived as suspicious or guilty by police.

We explored this possibility in Study 2 by comparing Black and White men's anticipated anxiety, self-regulatory efforts, and behavior in the hypothetical police encounter. Following Najdowski (2011), we predicted that Black men, but not White men, would expect to experience stereotype threat in the police encounter, and, in turn, Black men would anticipate feeling more anxiety and engaging in more self-regulatory efforts than White men. Ultimately, we expected this sequence to increase the likelihood that, relative to White men, Black men would imagine engaging in more nonverbal behaviors that police commonly perceive as deceptive.

\section{Method}

Participants. Participants were 79 Black and 100 White men from two samples: (a) undergraduate psychology students from the University of Illinois at Chicago and (b) from contexts where students were likely to be (e.g., on campus). See the procedure section for more details about the samples and their recruitment. The first sample was predominantly White $(94 \%)$ whereas the second sample was predominantly Black $(96 \%)$, and this difference in racial composition was significant, $\chi^{2}(1, N=179)=$ 144.40, $p<.001, \varphi=.90,95 \%$ CI [.80, .95]. On average, participants were 21 years old ( $S D=5$ years), although men in the first sample were significantly younger than men from the second sample $(M=19, S D=3$, and range $=17$ to 52 years old vs. $M=$ $24, S D=6$, and range $=15$ to 43 years old $), t(330)=-9.39, p<$ $.001, d=-1.42,95 \%$ CI $[-1.73,-1.10]$. Most participants were U.S. citizens in both the first (95\%) and second (97\%) samples, $\chi^{2}(1, N=176)=.54, p=.46, \varphi=.06,95 \%$ CI $[-.11, .15]$.

\section{Materials.}

Demographic factors measures. Participants reported their sex (as a proxy for gender), age, race/ethnicity, and U.S. citizenship status.

Thought-induction task. Instructions modified from Archer and colleagues (1979) and Haegerich and Bottoms (2000) were used to engage participants in active imagery concerning the hypothetical police encounter. Specifically, participants were told to:

Take a few minutes to read the next paragraph slowly and carefully. Imagine what it would be like if you were in the situation described 
below. Try hard to put yourself in the situation and really think hard about how you would be feeling in the situation. Think long and hard about how you would react. Try to reflect upon the way you would feel if you were in these circumstances.

Next, participants read this description of a hypothetical police encounter:

It's about 10:00 p.m. and you're on your way home for the night. You just got off the bus and you're walking down the street carrying a backpack filled with various things you needed throughout the day. Only two more blocks and you'll be home. Before you cross the street to get to your building, a police officer walks out of the corner convenience store, a little ways in front of you. When he sees you, he stops and stands there. The officer is obviously watching you as you approach.

Participants received two prompts to reinforce the thought induction. Specifically, before completing any measures, participants read, "In your mind's eye, perhaps you can visualize how it would feel for you to be in this situation." Before beginning the word-stem completion task, participants were reminded, "Please continue to imagine how you would feel in this situation as you complete this questionnaire."

Stereotype threat measures. Stereotype threat was measured implicitly as stereotype activation via spontaneous reactions to the thought-induction task and a word-stem completion performance. It was measured explicitly via general expectations regarding the hypothetical police officer's actions, expectations about being accused of wrongdoing, and the expected stereotype threat scale.

Spontaneous reactions. Stereotype activation was coded as yes or no based on participants' spontaneous reactions to the questions "How would you feel? What would you be thinking? How would you react?" The stereotype was considered to be activated when participants made spontaneous references to either (a) the stereotype of Black criminality or (b) concern about being perceived as a criminal because of a stereotype about a group to which they belonged. Two independent raters coded a random sample of responses $(20 \%)$ and achieved interrater agreement of $99 \%$. Disagreements were resolved by discussion. One rater coded the remaining data.

Word-stem completion performance. A word-stem completion task also assessed stereotype activation, following Goff, Steele, and Davies (2008) and Steele and Aronson (1995). In pretesting, 49 students and community members (10\% Black, 47\% White, 16\% Asian American, 18\% Hispanic/Latino, 2\% other, and 6\% multiracial; $53 \%$ men; $M$ age $=24, S D=7$, range $=18$ to 50 years old) listed words associated with the stereotype that Blacks are criminals. The 20 most common words were then selected and given to 25 other students and community members (28\% Black, $68 \%$ White, and 4\% Hispanic/Latino; $52 \%$ men; $M$ age $=31$, $S D=15$, range $=18$ to 66 years old), who rated each word for how strongly related it is to the target stereotype. The eight highest rated words were selected for use as stereotype-related stems in the word-stem completion task.

For each of the eight stereotype-related words (i.e., criminal, guns, drugs, poor, gangs, ghetto, thugs, and violent), two or three letter spaces were omitted so that the word stem could be completed with other, nonstereotype-related words (e.g., _R__INAL). These target word stems were intermixed randomly with 13 filler word stems that cannot be completed as words that would fit the stereotype (i.e., product, lunch, sheet, glove, blowing, sharing, reason, eraser, mover, funny, house, and stick). Participants were instructed to complete all 20 word stems with the first real words that came to their minds and to work quickly as they completed this task.

Stereotype activation was calculated as the ratio of target word stems the participant filled out in a stereotype-relevant manner (e.g., CRIMINAL as opposed to ORIGINAL) divided by the total number of target word stems the participant completed. Thus, higher scores on this measure reflect greater activation of the Black criminal stereotype.

Expectations about the officer's actions. Participants' openended responses to the question, "What do you imagine the police officer would do next?" were coded as 1 (positive), 2 (neutral), or 3 (negative). Expectations about the officer's actions were considered positive when participants' responses reflected beliefs that the officer would initiate a positive or beneficial interaction or outcome (e.g., "I would imagine the officer will protect me"); neutral when participants believed he would engage in a neutral interaction or outcome (e.g., "Say 'hello' as I walked past"); and negative when participants thought he would watch the participant with suspicion, stop or question the participant, or actively accuse the participant of wrongdoing (e.g., "Try to figure out if I was a criminal," "Approach me and maybe frisk me"). Two independent raters coded a random sample of responses (20\%) and achieved interrater agreement of $92 \%$. Disagreements were resolved by discussion. One rater coded the remaining data.

Expectations about being accused. Participants' expectations that they would be accused of wrongdoing by the officer were assessed by the question, "How concerned would you be that the police officer might accuse you of doing something wrong?" Responses were given on a 5-point scale ranging from 1 (not at all concerned) to 5 (extremely concerned), such that higher scores on this measure reflect greater anticipated concern about being accused of wrongdoing.

Expected stereotype threat scale. The 5 items from the modified version of the Explicit Stereotype Threat Scale (Goff, Steele, \& Davies, 2008; Marx \& Goff, 2005; Marx et al., 2005) used in Study 1 were further adapted to assess anticipated stereotype threat in the police encounter described (e.g., "I would worry that the police officer might stereotype me as a criminal because of my race). As in Study 1, responses were given on a 7-point scale ranging from -3 (strongly disagree) to 3 (strongly agree) and averaged to create the expected stereotype threat scale (overall: $\alpha=.92, M$ interitem correlation $=.68$; Blacks: $\alpha=.90, M$ interitem correlation $=.64$; Whites: $\alpha=.83, M$ interitem correlation $=.59$ ). Higher scores on this scale reflect greater expected stereotype threat in the hypothetical police encounter.

Anticipated anxiety scale. Seven items were created to assess anticipated anxiety in the hypothetical police encounter. Specifically, participants indicated the likelihood that they would feel anxiety when they encountered the police officer in the situation described (e.g., "I would feel anxious," "I would feel nervous," and "I would feel stressed"). Responses were given on a 5-point scale ranging from 1 (not at all likely) to 5 (extremely likely) and averaged to create the anticipated anxiety scale (overall: $\alpha=.89$, $M$ interitem correlation $=.54$; Blacks: $\alpha=.86, M$ interitem correlation $=.46$; Whites: $\alpha=.91, M$ interitem correlation $=.60$ ). 
Higher scores on this scale reflect greater likelihood of feeling anxious in the hypothetical encounter.

Anticipated self-regulatory efforts scale. Eight items were created to assess the extent to which participants thought it was likely they would think self-regulatory thoughts (i.e., thoughts directed at being vigilant to threat-related cues or self-monitoring efforts) in the hypothetical police encounter (e.g., "I would deliberately pay attention to how I was acting," "I would wonder what the police officer thought of me," and "I would be self-conscious about how I looked"). Responses were given on a 5-point scale ranging from 1 (not at all likely) to 5 (extremely likely) and averaged to create the anticipated self-regulatory efforts scale (overall: $\alpha=.81, M$ interitem correlation $=.34$; Blacks: $\alpha=.79$, $M$ interitem correlation $=.31$; Whites: $\alpha=.83, M$ interitem correlation $=.37$ ). Higher scores on this scale reflect greater likelihood of engaging in self-regulatory efforts in the hypothetical encounter.

Anticipated suspicious behavior scale. Anticipated suspicious behavior was assessed by asking participants to think about how they would act in the hypothetical police encounter and to rate the likelihood that they would "look nervous," "try to avoid looking nervous," "smile" (reverse-scored), "avoid making eye contact," or "freeze up," behaviors that police commonly perceive as deceptive (e.g., Akehurst et al., 1996; Vrij et al., 2006; Vrij \& Semin, 1996). Responses were given on a 5-point scale ranging from 1 (not at all likely) to 5 (extremely likely) and averaged to create the anticipated suspicious behavior scale. The internal reliability of the scale was poor initially (overall: $\alpha=.57, M$ interitem correlation $=.25$; Blacks: $\alpha=.56, M$ interitem correlation $=.23$; Whites: $\alpha=.55$, $M$ interitem correlation $=.25$ ), but dropping the "smile" item increased internal reliability to an acceptable level across all participants (overall: $\alpha=.66, M$ interitem correlation $=.36$ ) and in each subsample (Blacks: $\alpha=.61, M$ interitem correlation $=.30$; Whites: $\alpha=.69, M$ interitem correlation $=.40)$. Higher scores on this scale reflect greater likelihood of behaving in ways that police commonly perceive as suspicious during the hypothetical encounter.

Procedure. Based on Study 1 results showing that stereotype threat is experienced to a greater degree by Black men than Black women and our expectation that this difference would be magnified in more realistic conditions, we recruited only men participants. As in Study 1, undergraduate introduction to psychology students completed the materials in class during a mass-testing session in exchange for course credit. This sample included only six Black men, however, so additional recruitment was necessary.
Thus, participants were also recruited from contexts where students were likely to be, including around campus and various public settings in the university area (i.e., cafeterias, train stations, etc.). The additional recruitment was aimed specifically at increasing the number of Black men enrolled in the study. These participants received a candy bar for participating.

The thought-induction task and all measures were presented in a single questionnaire. Participants completed demographic factors measures first, because describing one's race was expected to prime participants' racial identity, which past research suggests facilitates the induction of stereotype threat in Black participants (Steele \& Aronson, 1995). Next, participants completed the thought-induction task. Participants then completed the spontaneous reactions measure, the word-stem completion task, the anticipated anxiety and self-regulatory efforts scales (these 15 items were intermixed), the expectations about the officer's actions measure, the expectations about being accused measure, the anticipated suspicious behavior scale, and, finally, the expected stereotype threat scale. Measures were presented in the order listed to avoid introducing bias into participants' responses. All participants were treated according to the University of Illinois at Chicago IRB guidelines.

\section{Results}

First, we present results from correlation analyses examining associations between measures of stereotype activation and expected stereotype threat, anxiety, self-regulatory efforts, and suspicious behavior. Results from these analyses are presented in Table 1. Second, we show results from the main analyses, a $\chi^{2}$ analysis and a multivariate analysis of variance (MANOVA) that examined effects of participants' race on dichotomous and continuous dependent measures, respectively. Means, $S D$ s, and univariate test statistics, effect sizes, and CIs are presented in Table 2. Third, we present results from observed variables path analyses that explored the ability of stereotype activation and expected stereotype threat to explain significant racial differences in anticipated anxiety, self-regulatory efforts, and suspicious behavior in the hypothetical police encounter. To preview, analyses revealed significant effects of race in the direction expected across most measures and supported the hypothesis that stereotype threat would lead Black men, but not White men, to expect to engage in more self-regulatory efforts, and, in turn, behave more suspiciously.

Table 1

Correlations Among Stereotype Activation and Expected Stereotype Threat, Anxiety, SelfRegulatory Efforts, and Suspicious Behavior

\begin{tabular}{lcccccccc}
\hline & 1 & 2 & 3 & 4 & 5 & 6 & 7 & 8 \\
\hline 1. Spontaneous reactions & - & .04 & $.21^{* *}$ & $.28^{* * *}$ & $.46^{* * *}$ & $.21^{* *}$ & .12 & .07 \\
2. Word-stem completion performance & & - & .06 & -.01 & .04 & .05 & -.07 & .11 \\
3. Expectations about officer's actions & & & - & $.39^{* * *}$ & $.35^{* * *}$ & $.32^{* * *}$ & $.20^{* * *}$ & $.22^{* * *}$ \\
4. Expectations about being accused & & & & - & $.57^{* * * *}$ & $.67^{* * * *}$ & $.52^{* * * *}$ & $.54^{* * * *}$ \\
5. Expected stereotype threat scale & & & & & - & $.44^{* * *}$ & $.43^{* * * *}$ & $.37^{* * * *}$ \\
6. Anticipated anxiety & & & & & - & $.69^{* * * *}$ & $.63^{* * * *}$ \\
7. Anticipated self-regulatory efforts & & & & & & $-61^{* * *}$ \\
8. Anticipated suspicious behavior & & & & & & & \\
\hline
\end{tabular}

*** $p \leq .01 . \quad{ }^{* * * *} p<.001$. 
Table 2

Main Effects of Race on Stereotype Activation and Expected Stereotype Threat, Anxiety, Self-Regulatory Efforts, and Suspicious Behavior

\begin{tabular}{|c|c|c|c|c|c|c|}
\hline & $\begin{array}{c}\text { Black men } \\
M(S D)\end{array}$ & $\begin{array}{l}\text { White men } \\
\qquad M(S D)\end{array}$ & $F(1,149)$ & $p$ & $\beta$ & $95 \% \mathrm{CI}$ \\
\hline Word-stem completion performance ${ }^{a}$ & $.23(.25)$ & $.19(.24)$ & .75 & .39 & .04 & $-.05-.12$ \\
\hline Expectations about officer's actions ${ }^{\mathrm{b}}$ & $2.50(.57)$ & $2.33(.51)$ & 3.48 & .06 & .17 & $-.01-.35$ \\
\hline Expectations about being accused ${ }^{c}$ & $2.65(1.31)$ & $2.01(1.16)$ & 9.59 & .002 & .64 & $.23-1.04$ \\
\hline Expected stereotype threat scale ${ }^{\mathrm{d}}$ & $.77(1.67)$ & $-1.91(1.16)$ & 133.30 & $<.001$ & 2.68 & $2.22-3.14$ \\
\hline Anticipated anxiety scale ${ }^{\mathrm{e}}$ & $2.78(1.10)$ & $2.35(1.00)$ & 5.89 & .02 & .43 & $.08-.78$ \\
\hline Anticipated self-regulatory efforts scale $\mathrm{e}^{\mathrm{e}}$ & $2.84(.89)$ & $2.52(.86)$ & 4.71 & .03 & .32 & $.03-.61$ \\
\hline Anticipated suspicious behavior scale ${ }^{\mathrm{e}}$ & $2.36(.79)$ & $2.03(.79)$ & 6.28 & .01 & .34 & $.07-.60$ \\
\hline
\end{tabular}

${ }^{a}$ Ratio of target word stems completed with stereotype-relevant words out of total target word stems completed. ${ }^{\mathrm{b}}$ Measured on a 3-point scale ranging from 1 (positive) to 3 (negative). ${ }^{\mathrm{c}}$ Measured on a 5-point scale ranging from 1 (not at all concerned) to 5 (extremely concerned). ${ }^{\mathrm{d}}$ Measured on a 7-point scale ranging from -3 (strongly disagree) to 3 (strongly agree). ${ }^{\mathrm{e}}$ Measured on 5-point scales ranging from 1 (not at all likely) to 5 (extremely likely).

Correlation analyses. We first conducted correlational analyses among our five stereotype-threat-related measures (i.e., the implicit measures of spontaneous reactions and word-stem completion performance, and the explicit measures of expectations about the officer's actions, expectations about being accused, and the expected stereotype threat scale) and the proposed downstream consequences of anticipated anxiety, self-regulatory efforts, and suspicious behavior (see Table 1 for results). Of interest, stereotype activation was significantly and positively related to the explicit measures of expected stereotype threat and anticipated anxiety when assessed with spontaneous reactions to the thoughtinduction task but not via word-stem completion performance. Thus, participants who spontaneously mentioned the stereotype of Black criminality after imagining the hypothetical police encounter were significantly more likely than others to think the officer would regard them as suspects and accuse them of wrongdoing and expect to experience stereotype threat and anxiety. Neither implicit measure of threat significantly related to anticipated self-regulatory efforts or suspicious behavior, however.

In contrast, as expected, all three explicit measures of stereotype threat were significantly and positively correlated with each other and also with anticipated anxiety, self-regulatory efforts, and suspicious behavior: The more participants had negative expectations about the officer's actions, expected to be accused of wrongdoing, and expected to feel stereotype threat, the more they anticipated feeling anxious, engaging in self-regulatory efforts, and behaving suspiciously in the imagined police encounter.

Main analyses. A $\chi^{2}$ analysis revealed that, as hypothesized, the stereotype of Black criminality was activated and cognitively accessible for significantly more Black men (27\%) than White men $(3 \%)$, as reflected by participants' spontaneous reactions to the thought-induction task, $\chi^{2}(1, N=169)=21.06, p<.001, \varphi=$ $.35,95 \%$ CI $[.19, .43]$. Examples of responses that reflected Black men's stereotype activation include "I would feel like he suspects me of doing something because I'm Black"; "I would think that the officer is racially profiling me and is probably thinking that I stole one of the items in my bookbag"; "I would think 'typical cop. They always suspect the tall Black man"”; and "Not surprised, because being Black people notice me at night, as if I'm a criminal."

The MANOVA revealed a significant multivariate effect of race on the measures of stereotype activation and expected stereotype threat, anxiety, self-regulatory efforts, and suspicious behavior, $F(7,143)=21.57, p<.001$, Wilk's $\lambda=.49$, partial $\eta^{2}=.51$. As displayed in Table 2, univariate tests revealed that performance on the word-stem completion task reflected similar levels of stereotype activation for Black and White men, and Black and White men reported statistically similar expectations about the officer's actions in the imagined encounter. In contrast, however, Black men were significantly more likely to expect that they would be accused of wrongdoing by the officer and anticipated feeling significantly more stereotype threat in the encounter. As in Study 1, supplementary $t$ tests comparing mean scores on the expected stereotype threat scale to the scale midpoint revealed that, whereas White men significantly disagreed that they would experience stereotype threat in the hypothetical police encounter, $t(98)=-16.21$, $p<.001, d=-1.63,95 \%$ CI $[-1.93,-1.33]$, Black men significantly agreed that they would, $t(76)=3.61, p=.001$, $d=.41,95 \%$ CI $[.18, .64]$. Also as predicted, Black men were significantly more likely than White men to anticipate feeling anxious, engaging in self-regulatory efforts, and behaving suspiciously in the imagined encounter.

Mediational analyses. Next, we tested (a) whether the five stereotype threat measures would predict anticipated anxiety and self-regulatory efforts and, in turn, anticipated suspicious behavior and (b) whether this model adequately explained the data for both Black and White men. We first tested for measurement invariance across groups using a structural equation modeling framework (AMOS 18; Arbuckle, 2009). Factor loadings for each scale were compared across Blacks and Whites with the most face valid item serving as the marker in all analyses (i.e., the variable for which the regression weight was set to 1). Pairwise comparisons revealed no significant differences among parameter estimates for the expected stereotype threat scale, $z \mathrm{~s}=-.01-.43, p \mathrm{~s} \geq .33$; anticipated anxiety scale, $z \mathrm{~s}=-.06-.13, p \mathrm{~s} \geq .45$; anticipated selfregulatory efforts scale, $z \mathrm{~s}=-.05-.08, p \mathrm{~s} \geq .47$; or anticipated suspicious behavior scale, $z \mathrm{~s}=-.06-.09, \mathrm{ps} \geq .46$. Based on these results and the fact that all scales were sufficiently reliable for both racial groups, the scales were entered into subsequent path analyses as observed variables.

Second, we sought to identify the best fitting baseline model. Multiple imputation based on 100 iterations was used to generate 


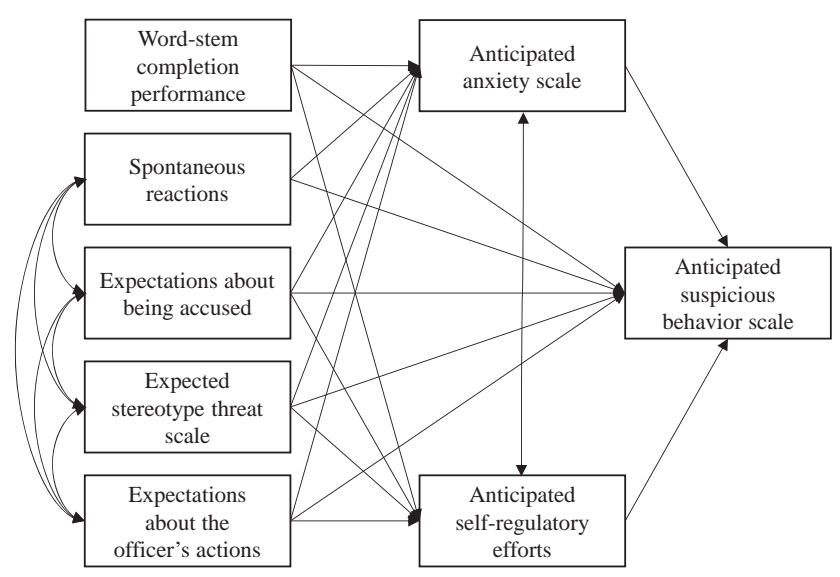

Figure 2. Originally specified model of the effect of stereotype activation and expected stereotype threat on anticipated suspicious behavior.

estimated values for missing data so analyses could be run on the full sample of 179 men. Analyses were based on the percentile bootstrap method with 1,000 samples, which is the recommended approach for assessing indirect effects (i.e., mediation; Shrout \& Bolger, 2002; Taylor, MacKinnon, \& Tein, 2008). As shown in Figure 2, the first model tested included all direct and indirect paths between the stereotype threat measures and anticipated anxiety, self-regulatory efforts, and suspicious behavior. Based on correlations (see Table 1), spontaneous reactions, expectations about the officer's actions, expectations about being accused, and the expected stereotype threat scale were allowed to covary, as were anticipated anxiety and self-regulatory efforts. Results indicated that the model was a mediocre fit to the data, $\chi^{2}(20, N=$ $179)=50.06, p<.001$, TLI $=.81$, RMSEA $=.09$, PCLOSE $=$ .02 . Thus, eight paths that were nonsignificant $(p>.10)$ for both Blacks and Whites were dropped to produce a more parsimonious model. Specifically, we eliminated nonsignificant paths from (a) word-stem completion performance to the anticipated anxiety and self-regulatory efforts scales, (b) spontaneous reactions to the anticipated self-regulatory efforts scale, (c) the expected stereotype threat scale and expectations about the officer's actions to the anticipated anxiety and anticipated suspicious behavior scales, and (d) the anticipated anxiety scale to the anticipated suspicious behavior scale. These modifications produced a good, close-fitting model, $\chi^{2}(24, N=179)=28.78, p=.23, \mathrm{TLI}=.98$, RMSEA $=$ .03, PCLOSE $=.71$.
In the previous models, paths were unconstrained and allowed to vary freely across groups. To test for multigroup invariance, we next constrained the parameters and covariances to be equal for Blacks and Whites. This significantly reduced model fit, $\chi^{2}(40$, $N=179)=80.12, p<.001$, TLI $=.88$, RMSEA $=.08$, PCLOSE $=.04$, and $\chi_{\text {diff }}^{2}(13)=51.34, p<.001$, showing that the estimates were significantly different across groups. Thus, results are discussed separately for Blacks and Whites. Direct effects, CIs, and significance levels are presented in Table 3 for covariances and in Table 4 for regression weights. Indirect effects, CIs, and significance levels are displayed in Table 5.

Explaining anticipated suspicious behavior among Black men. As depicted in Figure 3, there were significant positive associations among Black men's spontaneous reactions to the thought-induction task, expectations about the officer's actions, expectations about being accused, and expected stereotype threat in the imagined police encounter. The more the Black criminal stereotype was activated for Black men, the more negative they expected the officer's next actions to be, the more likely they thought it was that they would be accused of wrongdoing, and the more concerned they anticipated feeling about being perceived as a criminal on the basis of their race.

Neither word-stem completion performance nor spontaneous reactions to the imagined encounter related significantly to Black men's anticipated suspicious behavior. Spontaneous reactions were also not significantly associated with anticipated anxiety, but expectations about being accused were significantly and positively related to the degree to which Black men expected to experience anxiety in the hypothetical police encounter. Even so, anticipated anxiety did not translate into anticipated suspicious behavior. Anticipated anxiety and self-regulatory efforts were significantly related, but expecting to be accused did not predict greater anticipated self-regulatory efforts. Expecting to be accused did, however, lead Black men to be significantly more likely to anticipate behaving suspiciously in the encounter.

In contrast, both expected stereotype threat and expectations about the officer's actions had significant indirect effects on anticipated suspicious behavior, although the effects were not in the same direction. As predicted, Black men who expected to experience more stereotype threat in the encounter reported being significantly more likely to engage in self-regulatory efforts and, in turn, more likely to anticipate behaving suspiciously. Unexpectedly, however, Black men who had negative expectations about the officer's next actions reported being significantly less likely to

Table 3

Covariance Estimates, 95\% Confidence Intervals, and Significance Levels From Unconstrained Path Model

\begin{tabular}{|c|c|c|c|c|c|c|c|c|}
\hline \multirow[b]{2}{*}{ Parameter } & \multicolumn{4}{|c|}{ Black men } & \multicolumn{4}{|c|}{ White men } \\
\hline & Estimate & $\begin{array}{l}\text { Lower } \\
\text { bound }\end{array}$ & $\begin{array}{l}\text { Upper } \\
\text { bound }\end{array}$ & $p$ & Estimate & $\begin{array}{l}\text { Lower } \\
\text { bound }\end{array}$ & $\begin{array}{l}\text { Upper } \\
\text { bound }\end{array}$ & $p$ \\
\hline Spontaneous reactions $\leftrightarrow$ Expected stereotype threat scale & .35 & .21 & .48 & .002 & -.00 & -.02 & .01 & .59 \\
\hline Spontaneous reactions $\leftrightarrow$ Expectations about officer's actions & .10 & .05 & .15 & .002 & -.01 & -.02 & .00 & .06 \\
\hline Spontaneous reactions $\leftrightarrow$ Expectations about being accused & .22 & .09 & .33 & .002 & -.02 & -.05 & .00 & .06 \\
\hline Expectations about officer's actions $\leftrightarrow$ Expectations about being accused & .20 & .05 & .35 & .007 & .23 & .11 & .35 & .002 \\
\hline Expectations about officer's actions $\leftrightarrow$ Expected stereotype threat scale & .38 & .20 & .56 & .002 & .12 & -.02 & .25 & .10 \\
\hline Expectations about being accused $\leftrightarrow$ Expected stereotype threat scale & 1.28 & .82 & 1.73 & .002 & .74 & .45 & 1.12 & .002 \\
\hline Anticipated anxiety $\leftrightarrow$ Anticipated self-regulatory efforts & .29 & .14 & .46 & .002 & .27 & .17 & .37 & .002 \\
\hline
\end{tabular}


Table 4

Direct Effects, 95\% Confidence Intervals, and Significance Levels From Unconstrained Path Model

\begin{tabular}{|c|c|c|c|c|c|c|c|c|}
\hline & \multicolumn{4}{|c|}{ Black men } & \multicolumn{4}{|c|}{ White men } \\
\hline & Estimate & $\begin{array}{l}\text { Lower } \\
\text { bound }\end{array}$ & $\begin{array}{l}\text { Upper } \\
\text { bound }\end{array}$ & $p$ & Estimate & $\begin{array}{l}\text { Lower } \\
\text { bound }\end{array}$ & $\begin{array}{l}\text { Upper } \\
\text { bound }\end{array}$ & $p$ \\
\hline \multicolumn{9}{|l|}{ Effects on anticipated anxiety } \\
\hline Spontaneous reactions & .38 & -.07 & .78 & .08 & -.27 & -.49 & 7.65 & .09 \\
\hline Expectations about being accused & .40 & .24 & .55 & .002 & .59 & .42 & .75 & .002 \\
\hline \multicolumn{9}{|l|}{ Effects on anticipated self-regulatory efforts } \\
\hline Expected stereotype threat scale & .19 & .05 & .31 & .01 & .13 & -.05 & .27 & .15 \\
\hline Expectations about being accused & .10 & -.11 & .29 & .34 & .41 & .22 & .60 & .002 \\
\hline Expectations about officer's actions & -.19 & -.42 & -.02 & .04 & -.10 & -.33 & .10 & .31 \\
\hline \multicolumn{9}{|l|}{ Effects on anticipated suspicious behavior } \\
\hline Anticipated self-regulatory efforts & .37 & .17 & .57 & .002 & .58 & .41 & .75 & .002 \\
\hline Word-stem completion performance & .26 & -.64 & 1.12 & .56 & .38 & -.01 & .83 & .06 \\
\hline Spontaneous reactions & -.13 & -.57 & .32 & .59 & -.24 & -48.13 & -.05 & .03 \\
\hline Expectations about being accused & .16 & .02 & .31 & .03 & .15 & .01 & .27 & .04 \\
\hline
\end{tabular}

engage in self-regulatory efforts and, in turn, less likely to anticipate behaving suspiciously.

Explaining anticipated suspicious behavior among White men. Figure 4 shows that associations among stereotype activation and anticipated stereotype threat measures were less consistent among White than Black men. As with Black men, the word-stem completion performance did not have a significant effect on anticipated suspicious behavior. Unexpectedly, however, the implicit measure of spontaneous reactions was also not significantly related to the explicit measures of expectations about the officer's actions, expectations about being accused of wrongdoing, or expected stereotype threat in the imagined police encounter. Thus, White men who spontaneously thought of the Black criminal stereotype in reaction to the thought-induction task were no more or less likely than others to have negative expectations about what the officer would do next, expect to be accused of wrongdoing, or anticipate feeling concerned about being stereotyped as a criminal because of their race. Further, spontaneous reactions were not significantly related to anticipated anxiety, and a significant negative association between spontaneous reactions and anticipated behavior revealed that White men who spontaneously thought of the Black criminal stereotype were significantly less likely to anticipate that they would behave suspiciously in the hypothetical encounter.

Expecting to be accused of wrongdoing was significantly and positively related to both expectations about the officer's actions and anticipated stereotype threat, but the latter two measures were not significantly related to each other. Further, neither expecting more negative actions from the officer nor expecting to feel stereotype threat in the encounter were significantly associated with anticipated self-regulatory efforts. In contrast, White men who were more concerned about being accused of wrongdoing were significantly more likely to expect they would feel anxious and engage in self-regulatory efforts in the imagined situation, and only expectations of being accused had a significant indirect effect on anticipated suspicious behavior through anticipated selfregulatory efforts. Specifically, the more White men expected to be accused of wrongdoing in the hypothetical encounter, the more they anticipated they would engage in self-regulatory efforts and, in turn, the more likely they thought it was that they would behave in ways that police common perceive as suspicious. Even so, the relations between expectations about being accused and anticipated suspicious behavior were not accounted for entirely by self-regulatory efforts- the direct effect remained significant.

\section{Discussion}

Results provided further evidence that Black men, but not White men, experience stereotype threat in police encounters. Further, this study demonstrated that the racial difference in stereotype threat appears even when all participants envision the same kind of police encounter in terms of how likely it would have been for the police officer to confront them or target them as suspects. In addition, we found racial differences in anticipated anxiety, selfregulatory efforts, and suspicious behavior, such that Black men were significantly more likely than White men to think they would

Table 5

Indirect Effects of Expected Stereotype Threat Measures on Anticipated Suspicious Behavior, 95\% Confidence Intervals, and Significance Levels

\begin{tabular}{|c|c|c|c|c|c|c|c|c|}
\hline \multirow[b]{2}{*}{ Indirect effect on anticipated suspicious behavior } & \multicolumn{4}{|c|}{ Black men } & \multicolumn{4}{|c|}{ White men } \\
\hline & Estimate & $\begin{array}{l}\text { Lower } \\
\text { bound }\end{array}$ & $\begin{array}{l}\text { Upper } \\
\text { bound }\end{array}$ & $p$ & Estimate & $\begin{array}{l}\text { Lower } \\
\text { bound }\end{array}$ & $\begin{array}{l}\text { Upper } \\
\text { bound }\end{array}$ & $p$ \\
\hline Expectations about officer's actions & -.07 & -.17 & -.01 & .04 & -.06 & -.19 & .06 & .31 \\
\hline Expectations about being accused & .04 & -.04 & .12 & .34 & .24 & .11 & .39 & .002 \\
\hline Expected stereotype threat scale & .07 & .02 & .13 & .01 & .08 & -.03 & .16 & .15 \\
\hline
\end{tabular}




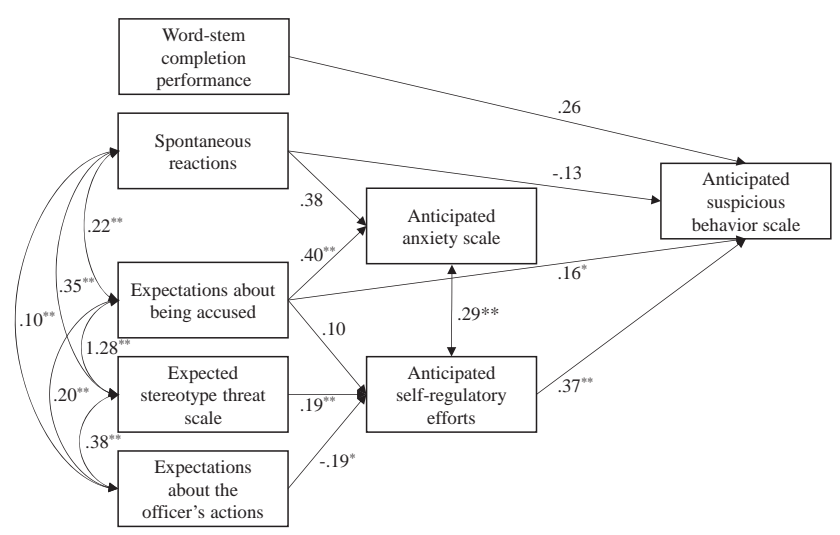

Figure 3. Trimmed model of the effect of stereotype activation and expected stereotype threat on anticipated suspicious behavior among Black men.

feel anxious, anticipate they would monitor the situation and their behavior for risk of being stereotyped, and, ironically, behave in ways that police have been shown to perceive as deceptive or suspicious (e.g., Akehurst et al., 1996).

Results provided mixed support for the proposed psychological process by which stereotype threat might affect behavior. To begin with, expecting to be accused of wrongdoing led both Black and White men to anticipate feeling more anxious in the hypothetical police encounter. However, contrary to our predictions and past research (e.g., Murphy et al., 2007), anticipated anxiety did not translate into anticipated behavior for either Black or White men. The sample size resulted in low power, however, so this and other important mediating processes might not have been detected by our analyses. Future research with larger samples should both explore that possibility and replicate the findings in more ecologically valid circumstances, as discussed later in greater detail.

As predicted and consistent with past research (Richeson \& Shelton, 2007), however, Black men who anticipated feeling stereotype threat in the imagined police encounter also anticipated that they would use self-regulatory efforts to avoid being stereotyped and, in turn, engage in suspicious-looking behavior. However, the more Black men thought the officer would watch them with suspicion, stop or question them, or actively accuse them of wrongdoing, the less likely they thought it was they would engage in self-regulatory efforts and, in turn, engage in suspicious-looking behavior. The latter finding can be considered in light of learned helplessness theory, which posits that individuals become motivationally, cognitively, and emotionally impaired in situations in which they believe their individual responses have no impact on uncontrollable outcomes (Abramson, Seligman, \& Teasdale, 1978). As a result of past personal or vicarious experiences of police discrimination, Black men might develop learned helplessness in police encounters, and come to believe that attempting to avoid being stereotyped as a criminal is a futile endeavor. Ironically, however, to the extent that such beliefs reduce the likelihood that Black men engage in certain suspicious-looking behaviors, it could actually lessen their risk of being subjected to investigatory contacts. It will be important for future research to take learned helplessness into account to better understand the impacts of Black men's police-related stereotype threat. In addition, the indirect effects of expected stereotype threat and expectations about the officer's next actions on anticipated suspicious behavior were opposite in direction but similar in strength, suggesting the effects might cancel each other out, but research is needed to determine if this is actually the case. This is especially important considering that Black men were significantly more likely than White men to anticipate behaving suspiciously in the hypothetical police encounter. If such racial differences cannot be explained entirely by effects of stereotype threat on anxiety or self-regulatory efforts, then other mediating processes must be identified and studied.

Although nonrace-specific expectations about being accused of wrongdoing had significant direct effects on anticipated anxiety and suspicious behavior in a police encounter for both Black and White men, they related to self-regulatory efforts for only White men. This is important because anticipating engaging in selfregulatory efforts was the largest predictor of anticipated suspicious behavior in both racial groups. These findings further support our hypothesis that, because Black men are uniquely concerned about being evaluated in light of the Black criminal stereotype, Black men and White men have different psychological experiences of police encounters. These racial differences in psychological experiences might manifest in behaviors that lead Black men to be perceived as more suspicious than White men by police.

Of importance, stereotype activation actually inoculated White men from expecting to behave suspiciously. This unexpected effect may be the result of stereotype lift, which Walton and Cohen (2003, p. 456) originally defined as "the performance boost caused by the awareness that an outgroup is negatively stereotyped." This effect has been shown to occur in academic contexts (Walton \& Cohen, 2003) and mounting evidence suggests that the phenomenon generalizes to a range of other stereotypes and other contexts (see, e.g., Cotner \& Burkley, 2013; Laurin, 2013). Future research might explore other effects of White men's nonstereotyped status, including whether salience of the Black criminal stereotype leads White men to feel invulnerable to police or even increases their likelihood of engaging in crime (see Hackney \& Glaser, 2013).

Finally, although there were links between spontaneous reactions and anticipated behavior among White men, the implicit measures of stereotype activation did not have the pervasive effects we expected. Previous work used the implicit measure of

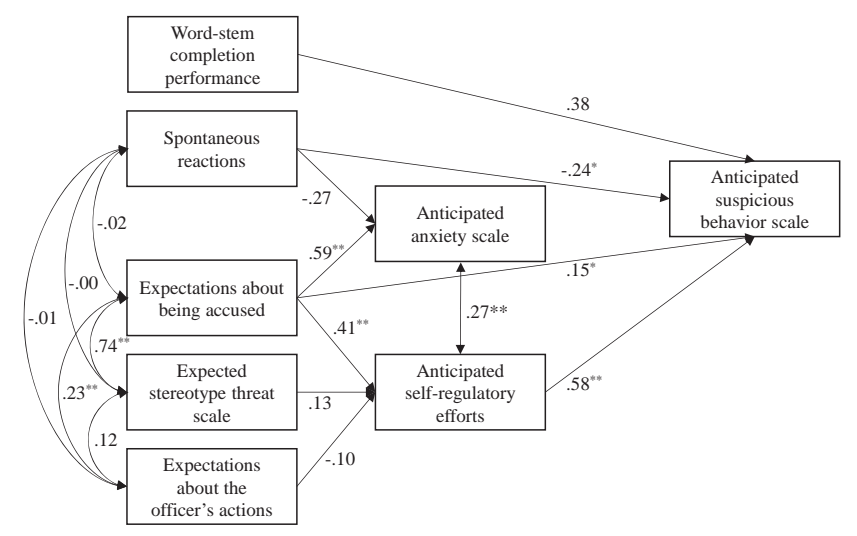

Figure 4. Trimmed model of the effect of stereotype activation and expected stereotype threat on anticipated suspicious behavior among White men. 
stereotype activation as an outcome or moderating variable (Steele \& Aronson, 1995), not as a mediator of distal effects as in the present work. It may be that stereotype activation is a necessary ingredient of stereotype threat but not sufficient on its own to elicit downstream consequences. That is, perhaps the stereotype must be cognitively activated and accessible for one to experience stereotype threat, but just because one is thinking of a stereotype does not mean he or she will be concerned about actually being stereotyped in any given situation. Additional elements, such as the perceived risk of being stereotyped in the moment, may be required for stereotype activation to translate into stereotype threat. Future research should seek to identify the exact perceptions and cognitive processes critical for producing the psychological experience of stereotype threat (see Steele et al., 2002).

\section{General Discussion}

We conducted two studies to explore how cultural stereotypes that depict Blacks as criminals might affect Blacks' experiences of police encounters. In Study 1, Blacks were significantly more likely than Whites to agree that, in general, they are concerned that police officers stereotype them as criminals simply because they are Black. Study 2 showed that this effect generalized to a hypothetical situation in which participants imagined coming face-toface with a police officer who was watching them. As predicted and consistent with Study 1, Black men were significantly more likely than White men to report that the hypothetical police encounter induced feelings of stereotype threat. An additional aim of this research was to test whether racial differences in stereotype threat translate into differences in anticipated nonverbal behavior, which might ultimately be misconstrued by police officers as evidence of guilt. As hypothesized, Study 2 suggested that expecting to be judged and treated unfairly because of the negative stereotype of Black criminality might cause Black men to behave differently-more "suspiciously"- than White men in encounters with police officers.

This work is the first to explore empirically the role of stereotype threat in Blacks' experiences of police encounters. However, there are limitations that should be noted. Even though Study 2 improved upon Study 1 by encouraging participants to imagine themselves in a very specific hypothetical police encounter, it still might have been difficult for participants to imagine how they would feel and the kinds of nonverbal behaviors that they would engage in during an actual police encounter. Research shows that people are sometimes not very good at predicting how they might feel in a given situation (Ayton et al., 2007), but, in line with Fishbein and Ajzen's (1975) theory of reasoned action, research suggests that intentions to engage in behavior accurately predict actual behavior (Sheppard, Hartwick, \& Warshaw, 1988; see also Epley \& Dunning, 2006; Kang, Lindell, \& Prater, 2007). Considering that interactions with police are salient experiences for which we develop a framework of expectations through legal socialization (e.g., Fagan \& Tyler, 2005), it is possible that predictions about anticipated feelings and behavior in police encounters might be at least somewhat accurate. In support, Blacks and Whites were fairly consistent in their estimations of stereotype threat across our two studies, yielding significant differences and large effect sizes. Even so, it would be ideal to test our hypotheses using more realistic circumstances, such as in a simulated police encounter or real encounters in the field. We expect that the differences we found would be magnified under more realistic conditions, but research is needed to bear this out.

It is also important to validate the use of our stereotype threat scale as a proxy measure of stereotype threat in the new domain of police encounters. Our measure was modified from a version originally developed to assess women's stereotype threat in a math test-taking situation (Marx et al., 2005). Adapted versions have been used to measure Blacks' stereotype threat when given a verbal test (Marx \& Goff, 2005) and Whites' concerns about appearing racist in conversations with Black partners (Goff, Steele, \& Davies, 2008), conditions in which the occurrence of stereotype threat has been well established (see Steele, 2010, and Richeson \& Shelton, 2012, respectively). In addition, past studies using the stereotype threat scale showed that it correlated with domainspecific performance (Marx \& Goff, 2005; Marx et al., 2005) and behavior (Goff, Steele, \& Davies, 2008). Thus, the extant literature suggests we can be confident that our measure accurately assessed Blacks' psychological experience of stereotype threat in police encounters, which was our primary goal. Exploring the downstream psychological and behavioral consequences of threat was a secondary aim of the current research, but one that should be pursued more rigorously in future research that incorporates objective outcomes. Given the foundational findings of our study, it now is clear that it would be worthwhile and beneficial for future studies to measure, for example, psychophysiological measures of anxiety (e.g., heart rate variability; see Murphy et al., 2007) and actual nonverbal behavior (e.g., eye contact; see Shelton, 2003; Vorauer \& Turpie, 2004). Such measures may produce a more accurate picture of how threat affects Blacks in police encounters.

Furthermore, measuring psychophysiological responses to threat and other constructs in future work would provide a more complete picture of the array of consequences stereotype threat might have. For example, to the extent that threat has psychophysiological consequences, Blacks who are frequently concerned about being subjected to bias-based policing could develop chronic health problems (e.g., hypertension, see Blascovich et al., 2001). In addition, through its effects on anxiety and self-regulatory efforts, stereotype threat might increase cognitive load and impair executive functioning (for reviews, see Najdowski, 2011, and Davis \& Leo, 2012). This could explain findings from other research showing that stereotype threat is associated with ego depletion and impaired self-control (Inzlicht, McKay, \& Aronson, 2006). Thus, stereotype threat might not only lead Blacks to behave in ways that police perceive as suspicious, but it could also make Blacks more susceptible to giving in to negative emotions and impulses than others, which could cause Blacks to experience more negative interactions with police officers. Inzlicht, Tullett, Legault, and Kang (2011) hypothesized that stereotype-threat-related selfregulatory decline could even lead Blacks to succumb to aggressive, violent, and criminal impulses more often than Whites. Furthermore as noted previously, Davis and Leo (2012) suggest that threatened Blacks might not have the self-regulatory resources needed to withstand the pressure to confess in interrogations and so threat might explain higher rates of false confessions among Blacks than Whites. The potential for such effects merits further attention.

Because stereotype threat is conditional upon situational factors that signal that one might be evaluated in terms of a stereotype 
(i.e., the stereotype is relevant), other researchers have used situational cues to explicitly activate stereotypes before experiments (e.g., Steele \& Aronson, 1995). We did not include control groups in our studies, wherein participants were not asked their race, so racial stereotypes might have been salient for all participants during the study. If another study were to reveal that stereotype threat manifests only when race is primed, that would be consistent with past work (e.g., Steele \& Aronson, 1995). The concepts of race and crime are automatically associated with each other (Eberhardt et al., 2004), however, and we believe related stereotypes are so salient in police encounters that participants would have responded similarly even if they had not indicated their race before completing our study materials. Indeed, our data were collected in 2010 and 2011, and police-related stereotype threat effects are probably even stronger now in light of recent racial tensions resulting from fatal confrontations between the police and unarmed Black men (e.g., Michael Brown, Eric Garner, Freddie Gray, etc.). A true control condition would need to strip away all characteristics that might activate stereotypes about race, crime, or the police, which would be impossible in a study of police interactions, like ours. Even so, future research could vary the extent to which the Black criminal stereotype is relevant in police encounters by, for example, varying whether a police confederate asks participants crime-relevant versus crime-irrelevant questions. Such research will be important for determining whether racial differences in police-related stereotype threat are elicited by the specific threat of being perceived in light of the stereotype, and whether these differences can be reduced in certain conditions.

It is also important to note that many variables could moderate the effects of stereotype threat found in this research. Study 1 suggests that gender is one such factor, with Black men at greater risk of experiencing stereotype in police encounters than Black women. Future research should also test for other moderating effects, including, for example, the race of the officer. Considering that $75 \%$ of local police officers are White and only $12 \%$ are Black (Reaves, 2010), our participants might have been imagining White officers. We did not, however, ask participants the race of the officer they were imagining, which could have several interesting effects on stereotype threat. Would Blacks feel less stereotype threat when confronted by a Black officer? On the one hand, Blacks paired with Black officers might feel "identity safety," or the sense that they will not be perceived in light of the criminal stereotype (Steele et al., 2002). This would be consistent with Marx and Goff's (2005) research showing that Blacks scored lower on intellectual tests than Whites when the experimenter was White, but performed just as well as Whites when the experimenter was Black. On the other hand, if the social categorization of police as outgroup members and authorities representing the White establishment is more salient than that of Blacks as ingroup members, then Blacks might experience just as much stereotype threat when interacting with a Black officer as a White officer.

In the context of interracial police encounters, beliefs about the extent to which a particular police officer is prejudiced or biasbased policing is widespread could affect Blacks' experiences of stereotype threat, too, as could individual differences in sensitivity to race-based rejection in interpersonal interactions in general (see Mendoza-Denton, Downey, Purdie, Davis, \& Pietrzak, 2002). However, stereotype threat is a situational threat, based on situational cues and the risk of being stereotyped in a specific situation
(Steele et al., 2002). Blacks' general beliefs that the police are prejudiced or race-based rejection sensitivity might be related to, but also distinct from feelings of stereotype threat. That is, contextual cues should exacerbate the perceived risk of being stereotyped unfairly as a criminal and discriminated against by police in actual encounters. It is important that future research measure all of these constructs to rule out alternative explanations and isolate the unique effects of stereotype threat.

Research on these kinds of issues is critical for understanding how and when situations are perceived as threatening versus safe and, thereby, the boundaries of stereotype threat effects in this important context. Participants' spontaneous reactions in Study 2 suggest that Blacks' feelings of stereotype threat are activated easily in police encounters, but there may be interventions that can attenuate Blacks' feelings of stereotype threat in police encounters. For example, community policing programs, which emphasize building trust and relationships with members of the public (see, e.g., Skogan \& Hartnett, 1997) could increase noninvestigatory police contacts with Blacks and increase Blacks' expectations that contacts with the police will be fair and just.

Finally, our research was focused on elucidating the role of stereotype threat in creating differences between Blacks' and Whites' experiences of police encounters, but other studies should test whether our findings generalize to other groups who are stereotyped as criminals (e.g., Hispanics, Muslims, etc.) and other situations in which that stereotype is relevant (e.g., in court, airport security checkpoints, etc.). Bringing social psychological theory on stereotype threat into such contexts might be useful for understanding and solving many real-world psycholegal problems.

\section{Implications for Theory and Practice}

Steele (2010) noted the "emerging generality of stereotype threat effects" (p. 97), but to our knowledge, this empirical research is the first to suggest that stereotype threat might occur in the novel context of police encounters. Thus, this work extends the boundaries of stereotype threat theory in regard to the domains in which the phenomenon occurs. It also contributes to our understanding of stereotype threat by shedding light on the range of consequences it can have for stereotyped groups. Indeed, a growing body of research indicates that stereotype threat has adverse behavioral effects with serious implications for a variety of interpersonal interactions (e.g., Apfelbaum, Sommers, \& Norton, 2008; Goff, Steele, \& Davies, 2008).

The results are also informative for understanding the applied problem of bias-based policing. Our studies provide evidence that Blacks think they would experience stereotype threat when they encounter police officers, and this could translate into an actual experience of threat in a real encounter. Study 2 further suggests that stereotype threat might, in turn, translate into suspiciouslooking behavior. The significance of this finding cannot be overstated because police often rely on suspect behavior when determining what actions to take, including whether to arrest (e.g., Stroshine, Alpert, \& Dunham, 2008). As evidence, New York Police Department (NYPD) officers cited citizens' "furtive movements" as the reason for 52\% of street stops in 2012 (New York Civil Liberties Union, 2013), and, as reviewed by Najdowski (2014), such furtive movements were used to explain stops significantly more often when citizens were Black rather than White. 
This disproportionality resulted in legal action against the city (Floyd v. City of New York, 2013), which was deemed to have violated citizens' Fourth Amendment right to protection against unreasonable search and seizure and Fourteenth Amendment right to equal protection under the law. Of note, Judge Shira Scheindlin ascribed the disproportionate stops and frisks of minorities to NYPD officers' unconscious bias and noted that, "There is no evidence that Black people's movements are objectively more furtive than the movements of White people" (p. 45). However, our finding that stereotype threat might affect behaviors that police commonly perceive as suspicious has implications for understanding why police officers target Blacks as suspects disproportionately more often than Whites. Of course, police officers should not have unbridled authority to stop Blacks more often than Whites because of racial differences in furtive movements. Rather, the use of such movements to justify stops needs to be evaluated carefully in terms of police policy and practice, and police and others should be trained that certain movements can be the product of normal psychological processes and not necessarily criminality.

These issues are also important to understand because innocent Blacks who are targeted by police because of stereotype-threatinduced behavior are at risk for miscarriages of justice (see Davis \& Leo, 2012; Najdowski, 2011, 2014). Misclassification errors aside, factors that contribute to bias in initial police interactions create opportunities for racial disparities at every subsequent step of the criminal justice process (e.g., in charging decisions, interrogations, jury voir dire, and verdicts). This work sheds light on the social psychological processes that contribute to these kinds of biases, which is an important step toward improving racial equity in the criminal justice system.

\section{References}

Abramson, L. Y., Seligman, M. E., \& Teasdale, J. D. (1978). Learned helplessness in humans: Critique and reformulation. Journal of Abnormal Psychology, 87, 49-74. http://dx.doi.org/10.1037/0021-843X.87 .1 .49

Akehurst, L., Köhnken, G., Vrij, A., \& Bull, R. (1996). Lay persons' and police officers' beliefs regarding deceptive behaviour. Applied Cognitive Psychology, 10, 461-471. http://dx.doi.org/10.1002/(SICI)10990720(199612)10:6<461::AID-ACP413>3.0.CO;2-2

Apfelbaum, E. P., Sommers, S. R., \& Norton, M. I. (2008). Seeing race and seeming racist? Evaluating strategic colorblindness in social interaction. Journal of Personality and Social Psychology, 95, 918-932. http://dx .doi.org/10.1037/a0011990

Arbuckle, J. L. (2009). AMOS (Version 18) [Computer Software]. Chicago, IL: Small Waters.

Archer, R. L., Foushee, H. C., Davis, M. H., \& Aderman, D. (1979). Emotional empathy in a courtroom simulation: A person-situation interaction. Journal of Applied Social Psychology, 9, 275-291. http://dx .doi.org/10.1111/j.1559-1816.1979.tb02711.x

Ayton, P., Pott, A., \& Elwakili, N. (2007). Affective forecasting. Why can't people predict their emotions. Thinking \& Reasoning, 13, 62-80. http://dx.doi.org/10.1080/13546780600872726

Beilock, S. L., Jellison, W. A., Rydell, R. J., McConnell, A. R., \& Carr, T. H. (2006). On the causal mechanisms of stereotype threat: Can skills that don't rely heavily on working memory still be threatened? Personality and Social Psychology Bulletin, 32, 1059-1071. http://dx.doi.org/ 10.1177/0146167206288489

Beilock, S. L., Rydell, R. J., \& McConnell, A. R. (2007). Stereotype threat and working memory: Mechanisms, alleviation, and spillover. Journal of Experimental Psychology: General, 136, 256-276. http://dx.doi.org/ 10.1037/0096-3445.136.2.256

Blascovich, J., Spencer, S. J., Quinn, D., \& Steele, C. (2001). African Americans and high blood pressure: The role of stereotype threat. Psychological Science, 12, 225-229. http://dx.doi.org/10.1111/14679280.00340

Bosson, J. K., Haymovitz, E. L., \& Pinel, E. C. (2004). When saying and doing diverge: The effects of stereotype threat on self-reported versus non-verbal anxiety. Journal of Experimental Social Psychology, 40, 247-255. http://dx.doi.org/10.1016/S0022-1031(03)00099-4

Carlson, D. K. (2004, July 20). Racial profiling seen as pervasive, unjust. Retrieved from http://www.gallup.com/poll/12406/Racial-ProfilingSeen-Pervasive-Unjust.aspx

Cheryan, S., \& Monin, B. (2005). "Where are you really from?": Asian Americans and identity denial. Journal of Personality and Social Psychology, 89, 717-730. http://dx.doi.org/10.1037/0022-3514.89.5.717

Cook, J. E., Arrow, H., \& Malle, B. F. (2011). The effect of feeling stereotyped on social power and inhibition. Personality and Social Psychology Bulletin, 37, 165-180. http://dx.doi.org/10.1177/0146167210390389

Correll, J., Park, B., Judd, C. M., \& Wittenbrink, B. (2002). The police officer's dilemma: Using ethnicity to disambiguate potentially threatening individuals. Journal of Personality and Social Psychology, 83, 1314-1329. http://dx.doi.org/10.1037/0022-3514.83.6.1314

Correll, J., Park, B., Judd, C. M., \& Wittenbrink, B. (2007). The influence of stereotypes on decisions to shoot. European Journal of Social Psychology, 37, 1102-1117. http://dx.doi.org/10.1002/ejsp.450

Correll, J., Park, B., Judd, C. M., Wittenbrink, B., Sadler, M. S., \& Keesee, T. (2007). Across the thin blue line: Police officers and racial bias in the decision to shoot. Journal of Personality and Social Psychology, 92, 1006-1023. http://dx.doi.org/10.1037/0022-3514.92.6.1006

Correll, J., Urland, G. R., \& Ito, T. A. (2006). Event-related potentials and the decision to shoot: The role of threat perception and cognitive control. Journal of Experimental Social Psychology, 42, 120-128. http://dx.doi .org/10.1016/j.jesp.2005.02.006

Cotner, C., \& Burkley, M. (2013). Queer eye for the straight guy: Sexual orientation and stereotype lift effects on performance in the fashion domain. Journal of Homosexuality, 60, 1336-1348. http://dx.doi.org/ 10.1080/00918369.2013.806183

Davis, D., \& Leo, R. A. (2012). Interrogation-related regulatory decline: Ego depletion, failures of self-regulation, and the decision to confess. Psychology, Public Policy, and Law, 18, 673-704. http://dx.doi.org/ 10.1037/a0027367

Devine, P. G. (1989). Stereotypes and prejudice: Their automatic and controlled components. Journal of Personality and Social Psychology, 56, 5-18. http://dx.doi.org/10.1037/0022-3514.56.1.5

Devine, P. G., \& Elliot, A. J. (1995). Are racial stereotypes really fading? The Princeton trilogy revisited. Personality and Social Psychology Bulletin, 21, 1139-1150. http://dx.doi.org/10.1177/01461672952111002

Duncan, B. L. (1976). Differential social perception and attribution of intergroup violence: Testing the lower limits of sterotyping of blacks. Journal of Personality and Social Psychology, 34, 590-598. http://dx .doi.org/10.1037/0022-3514.34.4.590

Duru, N. J. (2004). The Central Park Five, the Scottsboro Boys, and the myth of the bestial Black man. Cardozo Law Review, 25, 1315-1366.

Eberhardt, J. L., Goff, P. A., Purdie, V. J., \& Davies, P. G. (2004). Seeing black: Race, crime, and visual processing. Journal of Personality and Social Psychology, 87, 876-893.

Epley, N., \& Dunning, D. (2006). The mixed blessings of self-knowledge in behavioral prediction: Enhanced discrimination but exacerbated bias. Personality and Social Psychology Bulletin, 32, 641-655. http://dx.doi .org/10.1177/0146167205284007

Fagan, J., \& Tyler, T. R. (2005). Legal socialization of children and adolescents. Social Justice Research, 18, 217-241. http://dx.doi.org/10.1007/ s11211-005-6823-3 
Fishbein, M., \& Ajzen, I. (1975). Belief, attitude, intention, and behavior. Reading, MA: Addison Wesley.

Floyd v. City of New York, 08 Civ. 2274 (SAS), U.S. Dist. LEXIS 113205, (S. D. N. Y., August 12, 2013).

Goff, P. A., Steele, C. M., \& Davies, P. G. (2008). The space between us: Stereotype threat and distance in interracial contexts. Journal of Personality and Social Psychology, 94, 91-107. http://dx.doi.org/10.1037/ 0022-3514.94.1.91

Goff, P. A., Thomas, M. A., \& Jackson, M. C. (2008). “Ain't I a woman?”: Towards an intersectional approach to person perception and groupbased harms. Sex Roles, 59, 392-403. http://dx.doi.org/10.1007/s11199008-9505-4

Graham, S., \& Lowery, B. S. (2004). Priming unconscious racial stereotypes about adolescent offenders. Law and Human Behavior, 28, 483504. http://dx.doi.org/10.1023/B:LAHU.0000046430.65485.1f

Gregersen, T. S. (2005). Nonverbal cues: Clues to the detection of foreign language anxiety. Foreign Language Annals, 38, 388-400. http://dx.doi .org/10.1111/j.1944-9720.2005.tb02225.x

Hackney, A. A., \& Glaser, J. (2013). Reverse deterrence in racial profiling: Increased transgressions by nonprofiled whites. Law and Human Behavior, 37, 348-353. http://dx.doi.org/10.1037/lhb0000038

Haegerich, T. M., \& Bottoms, B. L. (2000). Empathy and jurors' decisions in patricide trials involving child sexual assault allegations. Law and Human Behavior, 24, 421-448. http://dx.doi.org/10.1023/A:1005592213294

Hagan, J., \& Albonetti, C. (1982). Race, class, and the perception of criminal injustice in America. American Journal of Sociology, 88, 329355. http://dx.doi.org/10.1086/227674

Hagan, J., Shedd, C., \& Payne, M. R. (2005). Race, ethnicity, and youth perceptions of criminal injustice. American Sociological Review, 70, 381-407. http://dx.doi.org/10.1177/000312240507000302

Harrigan, J. A., \& O'Connell, D. M. (1996). How do you look when feeling anxious? Facial displays of anxiety. Personality and Individual Differences, 21, 205-212. http://dx.doi.org/10.1016/0191-8869(96)00050-5

Hilton, J. L., \& Darley, J. M. (1985). Constructing other persons: A limit on the effect. Journal of Experimental Social Psychology, 21, 1-18. http://dx.doi.org/10.1016/0022-1031(85)90002-2

Hurwitz, J., \& Peffley, M. (1997). Public perceptions of race and crime: The role of racial stereotypes. American Journal of Political Science, 41, 375-401. http://dx.doi.org/10.2307/2111769

Inzlicht, M., McKay, L., \& Aronson, J. (2006). Stigma as ego depletion: How being the target of prejudice affects self-control. Psychological Science, 17, 262-269. http://dx.doi.org/10.1111/j.1467-9280.2006 .01695.x

Inzlicht, M., Tullett, A. M., Legault, L., \& Kang, S. K. (2011). Lingering effects: Stereotype threat hurts more than you think. Social Issues and Policy Review, 5, 227-256. http://dx.doi.org/10.1111/j.1751-2409.2011 .01031.x

Kang, J. E., Lindell, M. K., \& Prater, C. S. (2007). Hurricane evacuation expectations and actual behavior in Hurricane Lili. Journal of Applied Social Psychology, 37, 887-903. http://dx.doi.org/10.1111/j.1559-1816 .2007.00191.x

Krueger, J. (1996). Personal beliefs and cultural stereotypes about racial characteristics. Journal of Personality and Social Psychology, 71, 536548. http://dx.doi.org/10.1037/0022-3514.71.3.536

Laurin, R. (2013). Stereotype threat and lift effects in motor task performance: The mediating role of somatic and cognitive anxiety. The Journal of Social Psychology, 153, 687-699. http://dx.doi.org/10.1080/ 00224545.2013.821098

Lehman, B. J., \& Conley, K. M. (2010). Momentary reports of socialevaluative threat predict ambulatory blood pressure. Social Psychological \& Personality Science, 1, 51-56. http://dx.doi.org/10.1177/ 1948550609354924
Ludwig, J. (2003, May 13). Americans see racial profiling as widespread. Retrieved from http://www.gallup.com/poll/8389/Americans-SeeRacial-Profiling-Widespread.aspx

Madon, S., Guyll, M., Aboufadel, K., Montiel, E., Smith, A., Palumbo, P., \& Jussim, L. (2001). Ethnic and national stereotypes: The Princeton trilogy revisited and revised. Personality and Social Psychology Bulletin, 27, 996-1010. http://dx.doi.org/10.1177/0146167201278007

Major, B., \& O'Brien, L. T. (2005). The social psychology of stigma. Annual Review of Psychology, 56, 393-421. http://dx.doi.org/10.1146/ annurev.psych.56.091103.070137

Mann, S., \& Vrij, A. (2006). Police officers' judgements of veracity, tenseness, cognitive load and attempted behavioural control in real-life police interviews. Psychology, Crime \& Law, 12, 307-319. http://dx.doi .org/10.1080/10683160600558444

Mann, S., Vrij, A., \& Bull, R. (2004). Detecting true lies: Police officers' ability to detect suspects' lies. Journal of Applied Psychology, 89, 137-149. http://dx.doi.org/10.1037/0021-9010.89.1.137

Marx, D. M., \& Goff, P. A. (2005). Clearing the air: The effect of experimenter race on target's test performance and subjective experience. British Journal of Social Psychology, 44, 645-657. http://dx.doi .org/10.1348/014466604X17948

Marx, D. M., Stapel, D. A., \& Muller, D. (2005). We can do it: The interplay of construal orientation and social comparisons under threat. Journal of Personality and Social Psychology, 88, 432-446. http://dx .doi.org/10.1037/0022-3514.88.3.432

Mendes, W. B., Blascovich, J., Lickel, B., \& Hunter, S. (2002). Challenge and threat during social interactions with White and Black men. Personality and Social Psychology Bulletin, 28, 939-952. http://dx.doi.org/ 10.1177/01467202028007007

Mendes, W. B., Major, B., McCoy, S., \& Blascovich, J. (2008). How attributional ambiguity shapes physiological and emotional responses to social rejection and acceptance. Journal of Personality and Social Psychology, 94, 278-291. http://dx.doi.org/10.1037/0022-3514.94.2.278

Mendoza-Denton, R., Downey, G., Purdie, V. J., Davis, A., \& Pietrzak, J. (2002). Sensitivity to status-based rejection: Implications for African American students' college experience. Journal of Personality and Social Psychology, 83, 896-918. http://dx.doi.org/10.1037/0022-3514.83 .4 .896

Miller, C. T., \& Myers, A. M. (1998). Compensating for prejudice: How heavyweight people (and others) control outcomes despite prejudice. In J. Swim \& C. Stangor (Eds.), Prejudice: The target's perspective (pp. 191-218). San Diego, CA: Academic Press. http://dx.doi.org/10.1016/ B978-012679130-3/50044-2

Murphy, M. C., Steele, C. M., \& Gross, J. J. (2007). Signaling threat: How situational cues affect women in math, science, and engineering settings. Psychological Science, 18, 879-885. http://dx.doi.org/10.1111/j.14679280.2007.01995.x

Najdowski, C. J. (2011). Stereotype threat in criminal interrogations: Why innocent Black suspects are at risk for confessing falsely. Psychology, Public Policy, and Law, 17, 562-591. http://dx.doi.org/10.1037/ a0023741

Najdowski, C. J. (2014). Interactions between African Americans and police officers: How cultural stereotypes create a wrongful conviction pipeline for African Americans. In J. R. Acker \& A. D. Redlich (Eds.), Examining wrongful convictions: Stepping back, moving forward (pp. 55-70). Durham, NC: Carolina Academic Press.

Navarrete, C. D., McDonald, M. M., Molina, L. E., \& Sidanius, J. (2010). Prejudice at the nexus of race and gender: An outgroup male target hypothesis. Journal of Personality and Social Psychology, 98, 933-945. http://dx.doi.org/10.1037/a0017931

New York Civil Liberties Union. (2013). NYPD stop-and-frisk activity in 2012. Retrieved from http://www.nyclu.org/files/publications/ 2012_Report_NYCLU_0.pdf 
Oliver, M. B. (2003). African American men as "criminal and dangerous": Implications of media portrayals of crime on the "criminalization" of African American men. Journal of African American Studies, 7, 3-18. http://dx.doi.org/10.1007/s12111-003-1006-5

Payne, B. K. (2001). Prejudice and perception: The role of automatic and controlled processes in misperceiving a weapon. Journal of Personality and Social Psychology, 81, 181-192. http://dx.doi.org/10.1037/00223514.81.2.181

Plant, E. A., Goplen, J., \& Kunstman, J. W. (2011). Selective responses to threat: The roles of race and gender in decisions to shoot. Personality and Social Psychology Bulletin, 37, 1274-1281. http://dx.doi.org/ 10.1177/0146167211408617

Purdie-Vaughns, V., \& Eibach, R. P. (2008). Intersectional invisibility: The distinctive advantages and disadvantages of multiple subordinate-group identities. Sex Roles, 59, 377-391. http://dx.doi.org/10.1007/s11199008-9424-4

Quillian, L., \& Pager, D. (2001). Black neighbors, higher crime? The role of racial stereotypes in evaluations of neighborhood crime. American Journal of Sociology, 107, 717-767. http://dx.doi.org/10.1086/338938

Reaves, B. A. (2010). Local Police Departments, 2007. Washington, DC: U. S. Department of Justice, Bureau of Justice Statistics.

Richeson, J. A., \& Shelton, J. N. (2007). Negotiating interracial interactions: Costs, consequences, and possibilities. Current Directions in Psychological Science, 16, 316-320. http://dx.doi.org/10.1111/j.14678721.2007.00528.x

Richeson, J. A., \& Shelton, J. N. (2012). Stereotype threat in interracial interactions. In M. Inzlich \& T. Schmader (Eds.), Stereotype threat: Theory, process, and application (pp. 231-245). New York, NY: Oxford University Press.

Rome, D. (2004). Black demons: The media's depiction of the African American male criminal stereotype. Westport, CT: Praeger.

Schmader, T., Johns, M., \& Forbes, C. (2008). An integrated process model of stereotype threat effects on performance. Psychological Review, 115, 336-356. http://dx.doi.org/10.1037/0033-295X.115.2.336

Shelton, J. N. (2003). Interpersonal concerns in social encounters between majority and minority group members. Group Processes \& Intergroup Relations, 6, 171-185. http://dx.doi.org/10.1177/1368430203006002003

Sheppard, B., Hartwick, J., \& Warshaw, P. (1988). The theory of reasoned action: A meta-analysis of past research with recommendations for modifications and future research. Journal of Consumer Research, 15, 325-343. http://dx.doi.org/10.1086/209170

Shrout, P. E., \& Bolger, N. (2002). Mediation in experimental and nonexperimental studies: New procedures and recommendations. Psychological Methods, 7, 422-445. http://dx.doi.org/10.1037/1082-989X.7.4 .422

Sidanius, J., \& Veniegas, R. C. (2000). Gender and race discrimination: The interactive nature of disadvantage. In S. Oskamp (Ed.), Reducing prejudice and discrimination: The Claremont Symposium on Applied Social Psychology (pp. 47-69). Mahwah, NJ: Erlbaum.

Sigelman, L., \& Tuch, S. A. (1997). Metastereotypes: Blacks' perceptions of Whites' stereotypes of Blacks. Public Opinion Quarterly, 61, 87-101. http://dx.doi.org/10.1086/297788

Skogan, W. G., \& Hartnett, S. M. (1997). Community policing: Chicago style. New York, NY: Oxford University Press.

Smith, D. M., Neuberg, S. L., Judice, T. N., \& Biesanz, J. C. (1997). Target complicity in the confirmation and disconfirmation of erroneous perceiver expectations: Immediate and longer-term implications. Journal of Personality and Social Psychology, 73, 974-991. http://dx.doi.org/ 10.1037/0022-3514.73.5.974

Staples, B. (2007). Just walk on by: A black man ponders his power to alter public space. In J. F. Healey \& E. T. O’Brien (Eds.), Race, ethnicity, and gender: Selected readings (pp. 186-189). Thousand Oaks, CA: Pine Forge Press.
Steele, C. M. (2010). Whistling Vivaldi and other clues to how stereotypes affect us. New York, NY: Norton.

Steele, C. M., \& Aronson, J. (1995). Stereotype threat and the intellectual test performance of African Americans. Journal of Personality and Social Psychology, 69, 797-811. http://dx.doi.org/10.1037/0022-3514 69.5.797

Steele, C. M., Spencer, S. J., \& Aronson, J. (2002). Contending with group image: The psychology of stereotype and social identity threat. Advances in Experimental Social Psychology, 34, 379-440. http://dx.doi.org/ 10.1016/S0065-2601(02)80009-0

Strömwall, L. A., \& Granhag, P. A. (2003). How to detect deception? Arresting the beliefs of police officers, prosecutors and judges. Psychology, Crime \& Law, 9, 19-36. http://dx.doi.org/10.1080/10683160308138

Stroshine, M., Alpert, G., \& Dunham, R. (2008). The influence of "working rules" on police suspicion and discretionary decision making. Police Quarterly, 11, 315-337. http://dx.doi.org/10.1177/1098611107313029

Taylor, A. B., MacKinnon, D. P., \& Tein, J.-Y. (2008). Tests of the three-path mediated effect. Organizational Research Methods, 11, 241269. http://dx.doi.org/10.1177/1094428107300344

Thomas, E. L., Dovidio, J. F., \& West, T. V. (2014). Lost in the categorical shuffle: Evidence for the social non-prototypicality of black women. Cultural Diversity and Ethnic Minority Psychology, 20, 370-376. http:// dx.doi.org/10.1037/a0035096

Timberlake, J. M., \& Estes, S. B. (2007). Do racial and ethnic stereotypes depend on the sex of target group members? Evidence from a surveybased experiment. The Sociological Quarterly, 48, 399-433. http://dx .doi.org/10.1111/j.1533-8525.2007.00083.x

Vorauer, J. D., \& Turpie, C. A. (2004). Disruptive effects of vigilance on dominant group members' treatment of outgroup members: Choking versus shining under pressure. Journal of Personality and Social Psychology, 87, 384-399. http://dx.doi.org/10.1037/0022-3514.87.3.384

Vrij, A., Akehurst, L., \& Knight, S. (2006). Police officers', social workers', teachers' and the general public's beliefs about deception in children, adolescents and adults. Legal and Criminological Psychology, 11, 297-312. http://dx.doi.org/10.1348/135532505X60816

Vrij, A., \& Mann, S. A. (2001). Who killed my relative? Police officers' ability to detect real-life high-stake lies. Psychology, Crime \& Law, 7, 119-132. http://dx.doi.org/10.1080/10683160108401791

Vrij, A., \& Semin, G. R. (1996). Lie experts' beliefs about nonverbal indicators of deception. Journal of Nonverbal Behavior, 20, 65-80. http://dx.doi.org/10.1007/BF02248715

Vrij, A., \& Taylor, R. (2003). Police officers' and students' beliefs about telling and detecting trivial and serious lies. International Journal of Police Science \& Management, 5, 41-49. http://dx.doi.org/10.1350/ijps 5.1.41.11244

Vrij, A., \& Winkel, F. W. (1992). Social skills, distorted perception, and being suspect: Studies in impression formation and the ability to deceive. Journal of Police and Criminal Psychology, 8, 2-5. http://dx.doi.org/ 10.1007/BF02806606

Walton, G. M., \& Cohen, G. L. (2003). Stereotype lift. Journal of Experimental Social Psychology, 39, 456-467. http://dx.doi.org/10.1016/ S0022-1031(03)00019-2

Waxer, P. H. (1977). Nonverbal cues for anxiety: An examination of emotional leakage. Journal of Abnormal Psychology, 86, 306-314. http://dx.doi.org/10.1037/0021-843X.86.3.306

Welch, K. (2007). Black criminal stereotypes and racial profiling. Journal of Contemporary Criminal Justice, 23, 276-288. http://dx.doi.org/ $10.1177 / 1043986207306870$

Received January 14, 2014

Revision received April 17, 2015

Accepted April 25, 2015 